\title{
Effect of Biological Variables and Capture Period on the Proximate Composition and Fatty Acid Composition of the Dorsal Muscle Tissue of Hypophthalmus edentatus (Spix, 1829)
}

\author{
Edna Regina Netto de Oliveira ${ }^{1}$, Angelo Antonio Agostinho ${ }^{2}$ and Makoto Matsushita ${ }^{3}$ \\ ${ }^{I}$ Pharmacy and Pharmacology Department. ${ }^{2}$ NUPELIA; Biology Department ${ }^{3}$ Chemistry Department; State \\ University of Maringá; Av. Colombo 5790; 87020-900; Maringá - PR - Brazil
}

\begin{abstract}
This study analyzed the chemical composition of the dorsal muscle tissue of Hypophthalmus edentatus, in particular, fatty acids of the lipidic fraction, and its relationship with the biological variables and the capture period. The average values for moisture, ash, protein and total lipids were 63.15, 1.11, 14.27 and 17.24\%, respectively. In the lipidic fraction, 35 fatty acids were identified, the most abundant being: 16:0, 18:1 $\omega 9,18: 0,16: 1 \omega 7,18: 3 \omega 3, \mathrm{DHA}$ and EPA. The totals of respectively saturated, monounsaturated and polyunsaturated fatty acids were 41.15, 35.30 and $23.88 \%$. The PUFA/SFA ratio was equal to 0.68 and the $\omega 3 / \omega 6$ ratio equal to 1.98 . The PCA demonstrated that the long chain PUFAs contributed positively to the formation of the first axis. The CCA showed some effects of the biological factors (weight, reproductive cycle, sex) and the capture period on the variation of total lipids and some fatty acids.
\end{abstract}

Key words: Freshwater fish, fatty acids, lipid contents, proximate composition, Hypophthalmus edentatus

\section{INTRODUCTION}

Since the 1950s, many researchers have studied the chemical composition of teleosts, the lipidic fraction in particular, and its relationship with the biological, physiological and ecological characteristics of fish, in addition to its nutritional properties. The study of total lipids, different lipid categories and their fatty acid components allows evaluation of the dynamic of the compositions in several tissues of the fish during its different development phases, as well as the effect of seasonality on the metabolism of the fish (MacFarlane et al., 1993).

Lipids constitute a group of several natural chemical compositions capable of carrying out a variety of functions in living organisms. In fishes, (ectothermic animals), polar lipids (mainly phospholipids) act, basically, as structural components responsible for the maintenance of the fluidity of the plasmatic membrane, while neutral lipids (triacylglycerols) act as suppliers and stores of energy that will be used as fuel for the accomplishment of basic physiological functions, such as metabolism, migratory activity, growth and gonadal development (Henderson and Sargent, 1985; Brown and Murphy, 1995).

Studies about the lipid composition in freshwater fish have generally been made, using species of both temperate and boreal areas, but reports are also available on tropical and equatorial species. Although Brazil has important hydrographic 
basins, only some species were, until now, evaluated as regards total chemical composition (fatty acid composition in particular) (Gurgel and Freitas, 1977; Carvalho, 1980a; Maia et al., 1983; Saint-Paul, 1984; Junk, 1985; Gutierrez and Silva, 1993; Andrade et al., 1995; Inhamuns and Franco, 2001).

On the whole, freshwater fishes present a smaller quantity of polyunsaturated fatty acids (PUFA) of the $\omega 3$ family and a larger amount of $\omega 6-P U F A$ in relation to marine fish (Kinsella, et al., 1977; Henderson and Sargent, 1985; Ahlgren et al., 1994). They also present higher proportions of saturated fatty acids (SFA) and PUFA with 18 carbons, lower levels of PUFA with 20 and 22 carbons and a lower $\omega 3 / \omega 6$ ratio than the lipids of marine fish (Gruger et al., 1964; Viswanathan Nair and Gopakumar, 1978; Henderson and Tocher, 1987).

Hypophthalmus edentatus (Spix, 1829) (Osteichthyes, Siluriformes), known as mapará, sardela and perna-de-moça, is one of the five most caught species in the Itaipu reservoir (Agostinho et al., 1994a; Agostinho and Júlio Jr, 1999). It makes an important contribution to fishing and is the only zooplanktophagous-filterer species in the upper Paraná River basin (Benedito-Cecílio and Agostinho, 1999).

Considering the importance of mapará to fishing in the Itaipu Reservoir, in addition to the information available about the chemical composition of samples of this species from the Amazon basin (Carvalho, 1980a; Junk, 1985; Inhamuns and Franco, 2001), this work had as its objective to complement the study of the chemical composition of the dorsal musculature of mapará through the (i) evaluation of the moisture, ash, protein and total lipids, (ii) identification and relative quantification of the fatty acid components of its lipidic fraction, (iii) verification of the relationship between the different fatty acid components of the lipidic fraction and (iv) verification of the correlation between the total proximate composition and the fatty acids of the lipidic fraction with some biological variables (weight, length, sex, reproductive cycle and condition factor) and the capture period of the fish.

\section{MATERIALS AND METHODS}

Sampling and initial procedures. The $49 \mathrm{H}$. edentatus analyzed were captured in the Itaipu Reservoir - Paraná State/Brazil with the aid of gill nets in December 1998 and February and March 1999. After capture, the fishes were refrigerated, weighed and had their total and standard lengths measured. After being eviscerated, both sex and reproductive cycle were identified by direct visual examination of the gonads. The reproductive cycle was characterized as at rest (res), in maturation (mat), ripe (rip) and spent (spt) (Benedito-Cecílio, 1989). An adequate portion of dorsal muscle tissue (with white fibers and, in smaller amount, red fibers) from each fish was stored in a cylinder containing liquid nitrogen until analysis. The tissue was homogenized and divided into two portions, frozen $\left(-20^{\circ} \mathrm{C}\right)$ and analyzed in at most one week.

Analysis of the proximate composition. The first portion of homogenized tissue was used to determine water (AOAC, 1990), ash (AOAC, 1990) and protein content (Method of Kjeldhal, Pearson, 1973). The other was used to extract the total lipids (Bligh and Dyer, 1959), taking into account the proportions recommended between the methanol and chloroform solvents and the tissue moisture. An aliquot of the extracted lipid fraction was used to determine the total lipids in the samples (Maia, 1992). The remaining extract was concentrated in a rotary-evaporator at $35^{\circ} \mathrm{C}$ and frozen.

The results of the proximate composition are presented in median and the mean values are compared with the results of other authors in the discussion.

Metylation and chromatographic separation of the fatty acids. The stored extract was metylated (Maia, 1992) and the fatty acid methyl ester composition (FAME) was then determined by gas chromatography accomplished in a Shimadzu 14A chromatograph equipped with a flame ionization detector and a $50 \mathrm{~m}$ fused silica capillary column with a $0.22 \mathrm{~mm}$ internal diameter and polyethilenoglycol as liquid phase (Carbowax 20M). The following operational parameters were used: flame ionization detector temperature $245^{\circ} \mathrm{C}$; injection port temperature $220^{\circ} \mathrm{C}$; column temperature $150^{\circ} \mathrm{C}$ for $3 \mathrm{~min}$, programmed at a rate of $10^{\circ} \mathrm{C} \mathrm{min}^{-1}$ to a final temperature of $240^{\circ} \mathrm{C}$. 
Hydrogen was used as a carrier gas $\left(1.2 \mathrm{ml} \mathrm{min}^{-1}\right)$

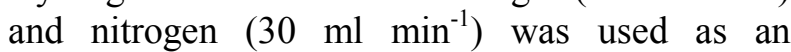
auxiliary gas. Flame gases were hydrogen $(30 \mathrm{ml}$ $\left.\min ^{-1}\right)$ and synthetic air $\left(300 \mathrm{ml} \mathrm{min}^{-1}\right)$ and the injection was operated in a split mode (1:100) with hexane as a solvent. A CG-300 integrator processor processed retention times and peaks areas. The results were given in percentage of each FAME in relationship to the total area of each peak in the chromatogram.

Identification of the fatty acids. Several procedures were used to identify the fatty acid methyl esters on chromatograms: technique of coelution (spiking) of standards and sample, comparison of the elution order (retention time) of FAMEs of the sample with standards (Sigma no. 189-19 and Standard Sigma of cod liver oil - USA) and mass spectrometry analysis using a gas chromatograph-mass spectrometer Shimadzu QP 2000 equipped with a $25 \mathrm{~m}$ capillary column with a $0.25 \mathrm{~mm}$ internal diameter (Carbowax 20M). In this case, the FAMEs were broken into fragments by an electronic impact of $70 \mathrm{eV}$.

Calculation of the condition factor. Standard length and weight data were used to calculate the condition factor of the fish, using the equation $\mathrm{W}$ $=a \mathrm{~L}^{b}$, where: $\mathrm{L}$ is the standard length; $\mathrm{W}$, the weight; $a$, an estimated coefficient and $b$, a value close to three in isometric growth, also estimated mathematically (Le Cren, 1951).

Statistical analysis. The non-parametric KruskalWallis Test (Siegel, 1975) was used to show the significant differences between the results of the determination of the water, ash, protein and total lipid content of the muscle in relation to the capture period and the reproductive cycle. Principal Components Analysis (PCA) was applied to summarize the variation of the fatty acid components of the lipidic fraction. Only the axes with eigenvalues larger than 1.0 (Kaiser-Guttman approach in Jackson, 1993) were retained for interpretation. Correlation Canonical Analysis (CCA) was applied to synthesize the relationships between the biological data (sex, weight, standard length, reproductive cycle and condition factor) and the capture period with the results of both the total chemical analysis and the composition of fatty acids (Harris, 1975; Johnson and Wichern, 1992). In order to carry out CCA, the reproductive cycles were summarized as: in reproduction (rip and spt) and non-reproduction (res and mat). The collection months were put into two groups: December, in the first and February and March, in the second. All statistical analysis was accomplished using the program STATISTICA 5.0 (STATSOFT - USA).

\section{RESULTS}

Proximate composition. Proximate composition was evaluated for $49 \mathrm{H}$. edentatus samples (20 females and 29 males). The median values for the total sample were (in \%): moisture, 63.15; ash, 1.11; protein, 14.27; and total lipids, 17.22. The moisture values were higher for females than for males (65.36 and $62.52 \%$, respectively), while the males presented larger values for total lipids than the females (18.73 and $14.27 \%$, respectively). Protein and ash values were almost similar between the two sexes, 14.13 and $1.11 \%$ for the females and 14.4 and $1.1 \%$ for the males, respectively (Fig. 1).

Although the capture of the fish had been concentrated in a short period (December, February and March), the chemical composition values of the dorsal muscle showed significant variations (Fig. 1). The differences happened mainly between December and March. In December, the highest values were for moisture $(69.01 \%)$ and protein $(16.51 \%)$ and the lowest for total lipids $(8.97 \%)$, while in March the lowest value was for moisture $(59.18 \%)$ and the highest for total lipids $(18.99 \%)$. In agreement with the Kruskal-Wallis Test, the variations were significant $(\mathrm{P}<0.05)$ for the moisture, protein and total lipid contents.

When the different reproductive cycles were considered, the medians for the moisture, ash, protein and total lipids did not present significant variations in the Kruskal-Wallis Test.

Composition and relative percentage of the fatty acids. In all thirty-five fatty acids were identified. The predominant ones, in decreasing order, were (in \%): palmitic acid (16:0), 25.24; oleic acid $(18: 1 \omega 9), 23.50$; stearic acid (18:0),

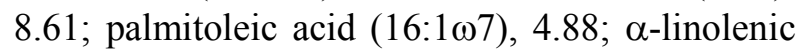
acid (18:3 $\omega 3), 4.09$; docosahexaenoic acid (DHA 22:6 $\omega 3), 3.42$ and eicosapentaenoic acid (EPA $20: 5 \omega 3)$, 3.29. Linoleic acid $(18: 2 \omega 6)$ and arachidonic acid $(20: 4 \omega 6)$ were presented in 
smaller amounts: 1.92 and $1.91 \%$, respectively (Table 1).

The totals of SFA, MUFA and PUFA were 41.15, 35.30 and $23.88 \%$, respectively. The mean PUFA/SFA ratio was equal to 0.68 . The values of $\omega 3$-PUFA and $\omega 6$-PUFA, $5.15 \%$ and $7.81 \%$, respectively, resulted in a $\omega 3 / \omega 6$-ratio equal to 1.98 (Table 1).

Principal Components Analysis. The first two axes of the PCA presented eigenvalues higher than 1. Therefore, they were retained for analysis. These two axes explained $48.03 \%$ of the data variability (25.97 and $22.06 \%$ for axes 1 and 2 , respectively). The fatty acids that most contributed to the formation of the first axis were 22:5 $\omega 6$,

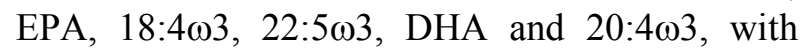
positive values for the linear Pearson's correlation.
Negative values for the correlation were registered

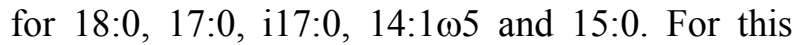
axis, the largest positive correlations were shown by the polyunsaturated fatty acids with a carbon number higher than 20 and the negatives ones by both the saturated and monounsaturated fatty acids with a carbon number equal or lower than 18 (Fig. 2A).

The fatty acids that were more positively related to the second principal component were 18:2 $\omega 6$,

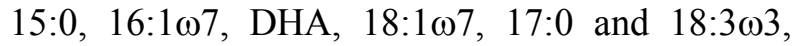
while those more negatively related were $18: 1 \omega 9$ and 20:1 $\omega 9$ (Fig. 2A). The PCA scores, derived from the samples analyzed, are shown in Fig. 2B.

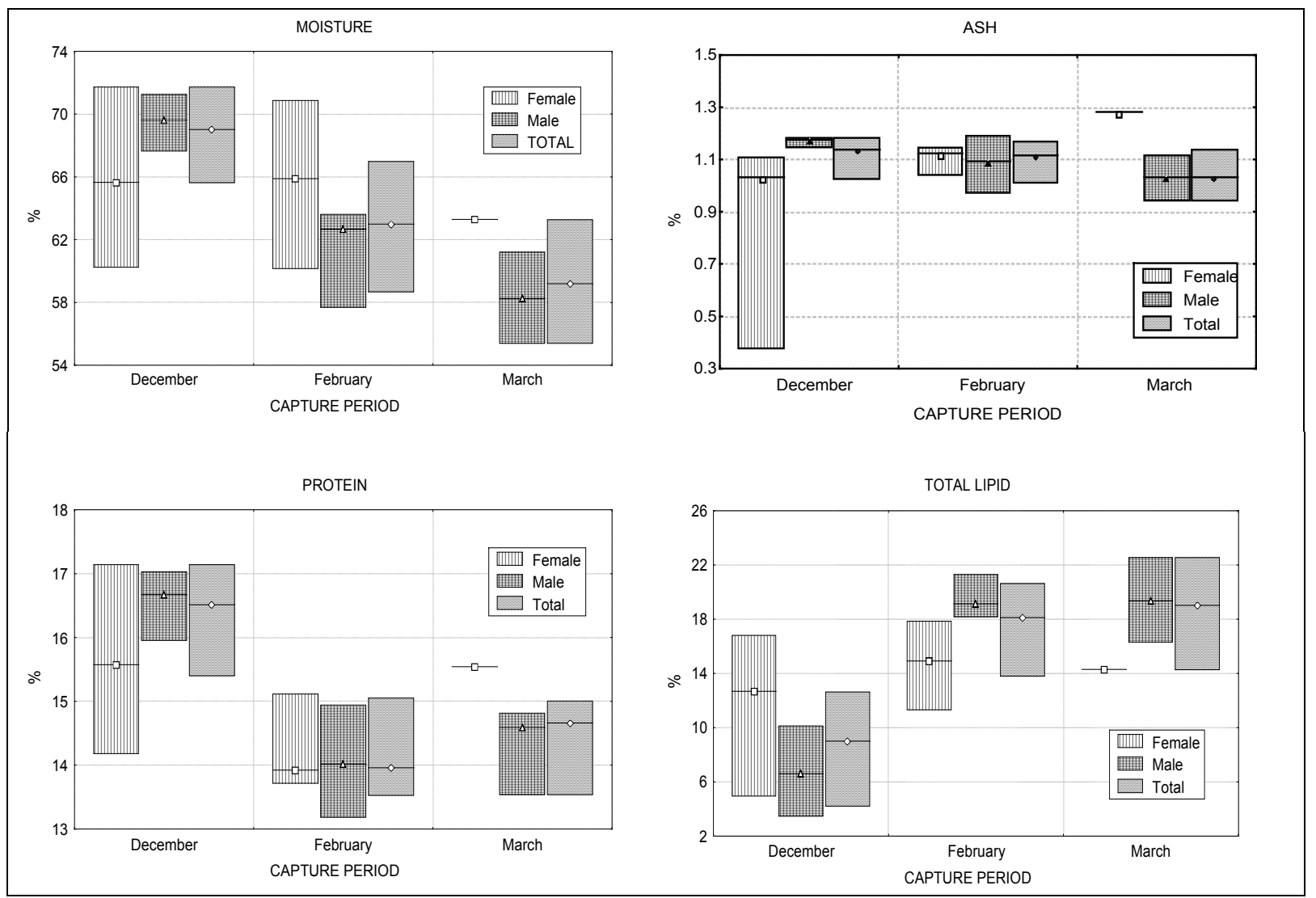

Figure 1 - Variation in moisture, ash, protein and total lipid content ( $\%$ humid base) of the dorsal muscle of females, males and the $H$. edentatus total during the capture months. The horizontal line indicates the median value and the inferior and superior portions correspond to quartis of $25 \%$ and $75 \%$, respectively. 
Table 1. The fatty acids identified in the total lipidic fraction of the dorsal muscular tissue of H. edentatus*.

\begin{tabular}{|c|c|c|c|}
\hline Fatty Acid & Females & Males & Total \\
\hline & Mean \pm sd & Mean \pm sd & Mean \pm sd \\
\hline 14:0 & $2.86 \pm 0.6$ & $2.75 \pm 0.7$ & $2.80 \pm 0.6$ \\
\hline $14: 1 \omega 5$ & $0.86 \pm 0.5$ & $0.92 \pm 0.3$ & $0.89 \pm 0.4$ \\
\hline 15:0 & $0.57 \pm 0.1$ & $0.55 \pm 0.1$ & $0.56 \pm 0.1$ \\
\hline 16:0 & $25.76 \pm 1.7$ & $24.88 \pm 2.0$ & $25.24 \pm 2.0$ \\
\hline $16: 1 \omega 9$ & $0.66 \pm 0.2$ & $0.55 \pm 0.2$ & $0.60 \pm 0.2$ \\
\hline $16: 1 \omega 7$ & $4.89 \pm 1.0$ & $4.88 \pm 1.0$ & $4.88 \pm 1.0$ \\
\hline i17:0 & $0.50 \pm 0.2$ & $0.58 \pm 0.2$ & $0.55 \pm 0.2$ \\
\hline ai17:0 & $0.28 \pm 0.1$ & $0.25 \pm 0.1$ & $0.26 \pm 0.1$ \\
\hline $17: 0$ & $1.32 \pm 0.3$ & $1.39 \pm 0.2$ & $1.36 \pm 0.2$ \\
\hline $17: 1 \omega 7$ & $0.39 \pm 0.1$ & $0.48 \pm 0.1$ & $0.44 \pm 0.1$ \\
\hline $18: 0$ & $8.27 \pm 0.9$ & $8.84 \pm 0.7$ & $8.61 \pm 0.8$ \\
\hline $18: 1 \omega 9$ & $22.93 \pm 3.6$ & $23.89 \pm 3.6$ & $23.50 \pm 3.6$ \\
\hline $18: 1 \omega 7$ & $2.26 \pm 0.7$ & $2.39 \pm 0.7$ & $2.34 \pm 0.7$ \\
\hline $18: 2 \omega 6$ & $1.94 \pm 0.4$ & $1.89 \pm 0.5$ & $1.91 \pm 0.5$ \\
\hline $18: 3 \omega 6$ & $0.25 \pm 0.1$ & $0.19 \pm 0.1$ & $0.21 \pm 0.1$ \\
\hline $18: 3 \omega 3$ & $4.40 \pm 1.0$ & $3.87 \pm 0.6$ & $4.09 \pm 0.8$ \\
\hline $18: 4 \omega 3$ & $0.88 \pm 0.2$ & $0.71 \pm 0.3$ & $0.78 \pm 0.3$ \\
\hline 20:0 & $0.44 \pm 0.2$ & $0.46 \pm 0.1$ & $0.45 \pm 0.1$ \\
\hline $20: 1 \omega 9$ & $2.01 \pm 0.5$ & $2.40 \pm 0.5$ & $2.24 \pm 0.5$ \\
\hline $20: 2 \omega 6$ & $0.39 \pm 0.2$ & $0.49 \pm 0.2$ & $0.45 \pm 0.2$ \\
\hline $20: 3 \omega 9$ & $0.44 \pm 0.2$ & $0.58 \pm 0.2$ & $0.52 \pm 0.2$ \\
\hline $20: 3 \omega 6$ & $0.37 \pm 0.2$ & $0.40 \pm 0.2$ & $0.39 \pm 0.2$ \\
\hline $20: 4 \omega 6$ & $1.96 \pm 0.4$ & $1.89 \pm 0.7$ & $1.92 \pm 0.6$ \\
\hline $20: 3 \omega 3$ & $0.74 \pm 0.3$ & $0.82 \pm 0.3$ & $0.79 \pm 0.3$ \\
\hline $20: 4 \omega 3$ & $1.29 \pm 0.5$ & $1.29 \pm 0.5$ & $1.29 \pm 0.5$ \\
\hline $20: 5 \omega 3$ & $3.52 \pm 0.6$ & $3.13 \pm 0.9$ & $3.29 \pm 0.8$ \\
\hline 22:0 & $0.69 \pm 0.2$ & $0.73 \pm 0.2$ & $0.72 \pm 0.2$ \\
\hline $22: 1 \omega 9$ & $0.31 \pm 0.2$ & $0.37 \pm 0.1$ & $0.34 \pm 0.1$ \\
\hline $22: 2 \omega 6$ & $0.34 \pm 0.3$ & $0.28 \pm 0.2$ & $0.30 \pm 0.2$ \\
\hline 23:0 & $0.41 \pm 0.2$ & $0.44 \pm 0.2$ & $0.43 \pm 0.2$ \\
\hline $22: 5 \omega 6$ & $2.15 \pm 0.6$ & $1.91 \pm 0.7$ & $2.01 \pm 0.6$ \\
\hline $22: 5 \omega 3$ & $1.16 \pm 0.3$ & $1.19 \pm 0.3$ & $1.18 \pm 0.3$ \\
\hline 24:0 & $0.39 \pm 0.1$ & $0.38 \pm 0.1$ & $0.38 \pm 0.1$ \\
\hline $22: 6 \omega 3$ & $3.66 \pm 0.6$ & $3.25 \pm 1.1$ & $3.42 \pm 1.0$ \\
\hline $24: 1 \omega 9$ & $0.34 \pm 0.1$ & $0.30 \pm 0.2$ & $0.31 \pm 0.1$ \\
\hline SFA & $41.26 \pm 2.4$ & $41.08 \pm 2.5$ & $41.15 \pm 2.5$ \\
\hline MUFA & $34.35 \pm 3.1$ & $35.95 \pm 3.4$ & $35.29 \pm 3.3$ \\
\hline PUFA & $24.34 \pm 4.2$ & $22.88 \pm 4.2$ & $23.47 \pm 4.2$ \\
\hline PUFA/MUFA & $0.72 \pm 0.2$ & $0.65 \pm 0.2$ & $0.68 \pm 0.2$ \\
\hline$\sum \omega 3$ & $15.94 \pm 2.6$ & $14.60 \pm 2.9$ & $15.15 \pm 2.8$ \\
\hline$\sum \omega 6$ & $7.99 \pm 1.9$ & $7.69 \pm 1.8$ & $7.81 \pm 1.8$ \\
\hline$\sum \omega 3 / \sum \omega 6$ & $2.05 \pm 0.4$ & $1.94 \pm 0.3$ & $1.98 \pm 0.3$ \\
\hline
\end{tabular}

* Results are expressed as a relative percentage of the total fatty acids present in the 19 females and 20 males analyzed.

Relationship between the chemical and biological variables and the capture period. The CCA showed significant relationships (first two axes; $\mathrm{P}<0.05$ ) between the biological data (sex, weight, reproductive cycle and condition factor) and the capture period with the general chemical composition (moisture, ash, protein, total lipids) and the more important fatty acids. The significant relationship between the data groups suggested an effect of the biological factors and the period on the total chemical and fatty acid composition in H.edentatus (Table 2).

In agreement with the values of Pearson's correlation between the original variables and the 
linear combinations inside of each data group, the chemical variables that contributed positively to the formation of the first axis were total lipids and $18: 1 \omega 9$, while the ones that were related negatively to this axis were protein, $16: 1 \omega 7$ and 14:0. Period was the most important variable on the axis, being positively related, while the biological variables, weight and reproductive cycle, were positively and negatively, respectively, related to the axis.

The chemical variables that contributed positively to the formation of the second axis were $20: 1 \omega 9$ and 18:0.
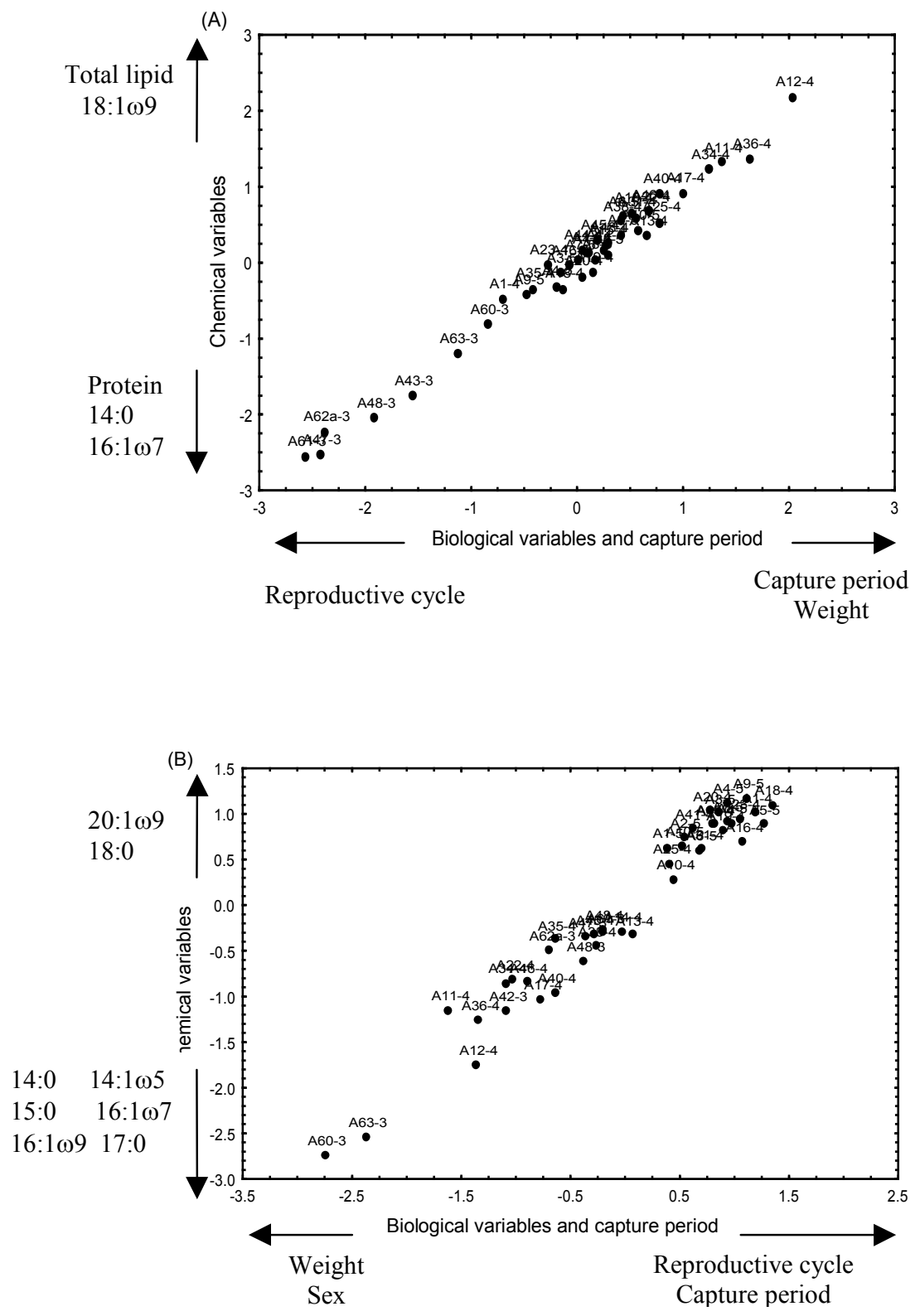

Figure 3 - Graphic score representation of axes 1 (A) and 2 (B) derived from the chemical composition data (y) and the biological variable/capture period data (x) for H. edentatus. Ay-x corresponds to: $\mathrm{Ay}=$ sample number, $\mathrm{x}=$ sampling month $(3=$ December, $4=$ February and $5=$ March). 
Table 2. CCA results accomplished between the total chemical composition data and the fatty acid data of the dorsal muscle of $H$. edentatus and the biological data and period of capture of the fish. $\mathrm{R}$ is the canonical correlation and $\chi^{2}$ refers to the sphericity test applied to the first two canonical axes.

\begin{tabular}{cccccc}
\hline Axes & $\mathbf{R}$ & $\mathbf{R}^{\mathbf{2}}$ & $\boldsymbol{\chi}^{\mathbf{2}}$ & $\mathbf{L D}$ & $\boldsymbol{P}$ \\
\hline 0 & 0.9904 & 0.9810 & 277.5 & 145 & $<\mathbf{0 . 0 0 1}$ \\
1 & 0.9786 & 0.9577 & 180.4 & 112 & $<\mathbf{0 . 0 0 1}$ \\
2 & 0.9131 & 0.8338 & 102.9 & 81 & 0.0507 \\
3 & 0.8666 & 0.7509 & 59.0 & 52 & 0.2358 \\
4 & 0.7990 & 0.6384 & 24.9 & 25 & 0.4669 \\
\hline
\end{tabular}

Those that contributed negatively were 14:0, 15:0, $16: 1 \omega 7, \quad 16: 1 \omega 9, \quad 17: 0$ and $14: 1 \omega 5$. Period contributed positively on this axis. Among the biological variables, the reproductive cycle had positive contribution, while weight and sex contributed negatively.

Figures $3 \mathrm{~A}$ and $3 \mathrm{~B}$ are graphic score representations of the chemical composition combined with the biological variables and the period for axes 1 and 2, respectively.

\section{DISCUSSION}

The mean value of $16.24 \%$ (median $=17.22 \%$ ) presented by the $H$. edentatus for the total lipids allowed it to be considered a high fat content species, in agreement with the classification proposed by Ackman (1989). Similar amounts were reported for this species in the Amazon area (Junk, 1985; Inhamuns, 2000). Other neotropical species that presented high amounts of total lipids in the muscle were Pinirampus pinirampu (19.75\%) and Colossoma mitrei (18.31\%) (Andrade et al., 1995).

The high percentage of muscle fat is very important for $H$. edentatus because of its important role in floatability. This species has an extremely reduced natatory bladder and pelagic habit, concentrating on the water surface (Agostinho et al., 1994 b). In addition to floatability, the high fat content should supply the metabolic needs of this species, which possesses intense mobility because of its zooplanktophagous-filterer habit (Lansac Tôha et al., 1991) and requires great amounts of oxygen, more abundant in the pelagic area (Carvalho, 1980b).

The evaluation of the dorsal muscle proximate composition of $H$. edentatus captured in Castanho Lake, Amazonas State demonstrated that the females presented mean fat values superior to the males ( 14.25 and $11.43 \%$, respectively) and mean protein values similar to the males (16.09 and 16.42\%, respectively) (Carvalho, 1980a). $H$. edentatus of the Itaipu Reservoir had mean protein values between males and females of $14.57 \%$ and $14.48 \%$, respectively; however, the total lipids presented larger differences between the sexes. The males presented means higher than the females $(17.57 \%$ and $14.32 \%$, respectively). $H$. edentatus, a high fat content fish, presented proportionally smaller protein amounts in its dorsal muscle because the storage of excess energy like muscle fat occured with the reduction in protein (Junk, 1985). Thus, in December, when the percentage of muscle lipids was lower than in the other months, the protein percentage was higher.

Junk (1985) and Inhamus and Franco (2001) have reported an inverse relationship between moisture and fat for $H$. edentatus of the Amazon basin. Protein and ash content did not present important variations.

The dynamics of the reproductive process of the fish depends on both intrinsic and extrinsic factors (Benedito-Cecílio, 1989). The lowest total lipid values obtained for $H$. edentatus in this work corresponded to the spawning period of the species (from October to December, Agostinho et al., 1994b). In this period, there is an accentuated diversion of somatic energy reserves for the development of reproductive organs and for the process of spawning itself. The fall in the nutritional level of this species in this period should also be linked to the formation of the growth ring in otoliths in the subsequent months. This happens during the slow growth period of the year (Ambrósio, 2000).

The pulse of the floods in the Itaipu Reservoir, with more than $90 \%$ of the rain falling from October to April, restricts primary production by limiting the passage of light (large amounts of particulate inorganic matter in suspension). There is also a loss of nutrients due to the reduction in the residence time of the water (Gomes and Miranda, 2001). Decrease in primary production 
leads to a reduction in the zooplanktonic community, the main item in the diet of the species in this study. Therefore, the full pulse of the floods, which is fundamental to complete the life cycle of fluvial fish, as demonstrated by Junk (1985), seems to have an adverse effect on the diet and nutritional condition of planktophagous organisms in reservoirs (Gomes and Miranda, 2001).

The reduction in food availability during the period of high precipitation and the increased spawning seemed to be the principal factors that contributed to the reduction in the total lipid values in the dorsal muscle of $H$. edentatus in the Itaipu Reservoir.

The composition pattern of the fatty acids observed in $H$. edentatus of the Itaipu reservoir, in general, did not differ from what was expected in freshwater species (Gruger et al., 1964; Ackman, 1967; Ågren et al., 1987; Wang et al., 1990; Gutierrez and Silva, 1993; Ahlgren et al., 1994), as it was very similar to what was observed by Inhamus and Franco (2001) in the same species in the Amazon and by Maia et al. (1983) in Prochilodus scrofa in the same area. It was, though, very different from that observed by Ågren et al. (1987) in freshwater fish in northern areas and by Wang et al. (1990) in freshwater species of Lake Superior (USA-Canada).

Andrade et al. (1995) have evaluated the fatty acids of 17 freshwater fish species marketed in the city of Maringá (Paraná State- Brazil). They found high interspecific variation in the amounts of SFA, total PUFA, $\omega 3$-PUFA and in the $\omega 3 / \omega 6$ ratio. However, the most abundant fatty acids among all the species were the same as those registered in this work. On the other hand, different from what is expected in freshwater species (Gruger et al., 1964; Viswanathan Nair and Gopakumar, 1978;

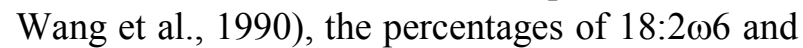
20:4 $\omega 6$, fatty acids of significance physiological importance were very low in $H$. edentatus when compared to those reported by some authors in marine fish, frequently deficient in $\omega 6$ fatty acids. Linoleic acid, an essential fatty acid in fish and man, is the precursor of arachidonic acid that, by means of both elongation and desaturation reactions, gives origin to the longer chain $\omega 6$ PUFAs (Gibson, 1983). These were also present in small amounts in $H$. edentatus. Very low fatty acid values were observed by Gutierrez and Silva (1993) in other Brazilian fresh water species, e.g.
Pseudoplatystoma corruscans, Pimelodus maculatus and Hoplias malabaricus.

The main $\omega 3$ polyenoic fatty acids responsible for the $\omega 3 / \omega 6$ - ratio being equal to 1.98 are $18: 3 \omega 3$, EPA and DHA. Ahlgren et al. (1994) considered this ratio as the main indicator of lipid quality in fish and that it best reflected the food quality of the fish. In freshwater fish, its value was, in general, lower than in marine fish, indicating for

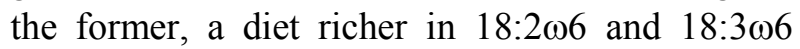
than in 18:3 03 (Ackman, 1967).

Palmitic acid (16:0), with more than $60 \%$ of the total SFA, was pointed out by Ackman and Eaton (1966) as a key metabolite in fish, whose amount did not depend on diet. This independence was reflected in the smaller variation coefficient observed for this fatty acid (7.7\%). Similar values for the fatty acid were observed in Australian freshwater and marine fish (Gibson, 1983), in Brazilian freshwater fish (Andrade et al., 1995), in tilapia (Oreochromis niloticus) from African lakes (Zenebe et al., 1998), in several North American freshwater species (Wang et al., 1990) and in Finnish freshwater species (Ågren et al., 1987).

The PCA results demonstrated the existence of an inverse relationship between long chain PUFA and short chain SFA and MUFA on the first axis. Inverse relationships between PUFA and SFA seemed to be a consistent pattern in several fish species (Ågren et al., 1987; Ahlgren et al., 1994). On the second axis, the inverse association was

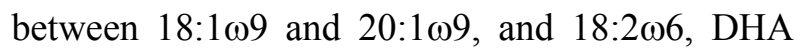
and 18:3 $\omega 3$, indicating that an increase in the fatty acids of both the $\omega 6$ and $\omega 3$ family was accompanied by a reduction in those of the $\omega 9$ family.

Capture period was the variable that contributed most to the variations in the chemical composition of the fish, followed by the variables weight and reproductive cycle. In addition, the increase in weight was accompanied by an increase in fat deposits and a reduction in muscle protein. Increase in lipids was almost always due to triacylglycerol accumulation in the tissues, which could be confirmed by the simultaneous increase in oleic acid, generally associated to that lipid class (Kanazawa, 1985; Greene and Selivonchick, 1987). The CCA demonstrated that the metabolism of the H. edentatus dorsal muscle was influenced by the capture period and almost all biological variables. 
The dynamics of proteins, total lipids and fatty acids, important chemical compounds involved in fish energy metabolism, were demonstrated to be related to sex, reproductive cycle and capture period of the fish. As these variables were influenced by other biotic and abiotic variables such as hydrologic level, pluviometric index, food availability and others, a conclusion about the dynamics required a deeper study involving a longer period of analysis and an additional control of the largest possible number of variables.

\section{ACKNOWLEDGEMENTS}

We thank the Itaipu Binacional and Nupelia/Universidade Estadual de Maringá for supporting us during the field sampling.

\section{RESUMO}

Este trabalho teve como objetivo estudar a composição química da musculatura dorsal de Hypophthalmus edentatus, em particular, a composição dos ácidos graxos da fração lipídica, e relacionar esta composição com variáveis biológicas e o período de coleta. Os valores de mediana para umidade, cinzas, proteína e lipídio total foram $63,15 \%, 1,11 \%, 14,27 \%$ e $17,24 \%$, respectivamente. $\mathrm{Na}$ fração lipídica foram identificados 35 ácidos graxos sendo os mais abundantes: 16:0, 18:1 $\omega 9,18: 0,16: 1 \omega 7,18: 3 \omega 3$, DHA e EPA. Os totais de ácidos graxos saturados, monoinsaturados e poliinsaturados foram, respectivamente, $41,15 \%, 35,30 \%$ e $23,88 \%$. A razão AGPI/AGS foi igual a 0,68 e a razão $\omega 3 / \omega 6$ igual a 1,98 . Na ACP contribuíram positivamente para formação do primeiro eixo AGPIs de cadeia longa e, negativamente, alguns AGSs e AGMIs de 14 a 18 carbonos. A análise de variáveis canônica sugere a existência de algum efeito de fatores biológicos (peso, estádio, sexo) e do período de coleta sobre a variação de alguns dos componentes químicos do tecido muscular dorsal de $H$. edentatus, principalmente, lipídios totais e alguns ácidos graxos.

\section{REFERENCES}

Ackman. R. G. (1967), Characteristics of the fatty acid composition and biochemistry of some freshwater fish oils and lipids in comparison with marine oils and lipids. Comp. Bioch. Physiol., 22, 907-922.

Ackman. R. G. (1989), Nutritional composition of fats in seafoods. Progr. Food Nutr. Sci., 13, 161-241.

Ackman, R. G. and Eaton, C. A. (1966), Some commercial Atlantic herring oils: fatty acid composition. J. Fish. Res. B. Can., 23, 991-1006.

Agostinho, A. A. and Júlio Jr., H. F. (1999), Peixes da Bacia do Alto Rio Paraná. In: Lowe-McConnell, R. H. (ed.). Estudos Ecológicos de Comunidades de Peixes Tropicais. São Paulo : EDUSP. pp. 374-400.

Agostinho, A. A.; Borghetti, J. R.; Vazzoler, A. E. A. M. and Gomes, L. C. (1994a), Itaipu reservoir: impacts on the ichthyofauna and biological bases for its management. In: United Nations Center for Regional Development (ed.). Environmental and social dimensions of reservoir development and management in La Plata River Basin. Nagoya : UNCRD Research Report Series. pp. 135-148.

Agostinho, A. A.; Júlio Jr., H. F. and Petrere Jr., M. (1994b), Itaipu reservoir (Brazil): impacts of the impoundment on the fish fauna and fisheries. In: Cowx, I. G. (ed.). Rehabilitation of Freshwater Fisheries. Oxford : Fishing News Books. pp. 171-184.

Agren, J.; Muje, P.; Hanninen, O.; Herranen, J. and Penttila, I. (1987), Seasonal variations of lipid fatty acids of boreal freshwater fish species. Comp. Bioch. Phys., 88B, 905-909.

Ahlgren, G.; Blomqvist, P.; Boberg, M. and Gustafsson, I. B. (1994), Fatty acid content of the dorsal muscle an indicator of fat quality in freshwater fish. J. Fish Biol., 45, 131-141.

Ambrosio, A. M. (2000), A pesca e o rendimento pesqueiro e estudos sobre idade e crescimento em dois períodos distintos de Hypophthalmus edentatus (Spix, 1829), (Siluriformes, Hypophthalmidae), do reservatório de Itaipu - PR, Brasil. Thesis, Universidade Estadual de Maringá, Brasil.

Andrade, A. D.; Rubira, A. F.; Matsushita, M. and Souza, N. E. (1995), 13 Fatty acids in freshwater fish from south Brazil. JAOCS, 72, 1207-1210.

AOAC (1990), Official methods of analysis. Association of Official Analytical Chemists $15^{\text {th }}$ ed. Arlington.

Benedito-Cecílio, E. (1989), Estrutura da população, reprodução e seletividade amostral de Hypophthalmus edentatus (Spix, 1829) (Osteichthyes, Siluriformes) no reservatório de Itaipu - PR. Dissertation, Universidade Federal do Paraná, Curitiba, Brazil.

Benedito-Cecílio, E. and Agostinho, A. A. (1999), Determination of patterns of ichthyofauna cooccurrence in the Paraná river basin, area of influence of the Itaipu reservoir. Interciência, 24, 360-365. 
Bligh, E. G. and Dyer, W. J. (1959), A rapid method of total lipid extraction and purification. Can. J. Bioch. Phys., 37, 911-917.

Brown, M. L. and Murphy, B. R. (1995), Effects of season, maturity, and sex on lipid class dynamics in largemouth bass (Micropterus salmoides Lacepede). Ecol. Fresh. Fish, 4, 124-130.

Carvalho, F. M. (1980a), Composição química e reprodução do mapará (Hypophthalmus edentatus Spix, 1829) do lago do Castanho, Amazonas (Siluriformes, Hypophthlmidae). Acta Amazônica, 10, 379-389.

Carvalho, F. M. (1980b), Alimentação do mapará (Hypophthalmus edentatus Spix, 1829) do lago do Castanho, Amazonas (Siluriformes, Hypophthlmidae). Acta Amazonica, 10545-555.

Gibson, R.A. (1983), Australian fish - an excellent source of both arachidonic acid and $\omega-3$ polyunsaturated fatty acids. Lipids, 18, 743-752.

Gomes, L. C. and Miranda, L. E. (2001), Hydrologic and climatic regimes limit phytoplankton biomass in reservoirs of the Upper Paraná River Basin, Brazil. Hydrobiologia, 457, 205-214.

Greene, D. H. S. and Selivonchick, D. P. (1987), Lipid metabolism in fish. Progr. Lipid Res., 26, 53-85.

Gruger, H. E.; Nelson Jr., R. W. and Stansby, M. E. (1964), Fatty acid composition of oil from 21 species of marine fish, freshwater fish and shellfish. JAOCS, 41, 662-667.

Gurgel, J. J. S. and Freitas, J. V. F. (1977), Variação estacional do teor de gordura da curimatã comum, Prochilodus cearensis Steindachner, pescada do piauí, Plagioscion squamosissimus (Heckel) e traíra, Hoplias malabaricus (Bloch) no açude Orós, em Orós, Ceará. Bol. Téc. DNOCS, 35, 149-163.

Gutierrez, L. E. and da Silva, R. C. M. (1993), Fatty acid composition of commercially important fish from Brazil. Sci. Agr., 50478-483.

Harris, R. J. (1975), A primer of multivariate statistics. New York: Academic Press.

Henderson, R. J. and Sargent, J. R. (1985), Fatty acid metabolism in fish. In: O'Ggrady, K. T. and Spillet, P. B. (ed.). Nutrition and feeding in fish. London : Academic Press. pp. 349-364.

Henderson, R. J. and Tocher, D. R. (1987), The lipid composition and biochemistry of freshwater fish. Prog. Lipid Res., 26281-347.

Inhamuns, A. J. and Franco, M. R. B. (2001), Composition of Total, Neutral and Phospholipids in Mapará (Hypophthalmus sp.) from Brazilian Amazon Area. J. Agric. Food Chem., 49, 4859-4863.

Jackson, D. A. (1993), Stopping rules in principal component analysis: a comparison of heuristical and statistical approaches. Ecology, 7,22204-2214.

Johnson, R. A. and Wichern, D. W. (1992), Applied multivariate statistical analysis. London : Prentice-Hall.
Junk, W. J. (1985), Temporary fat storage, an adaptation of some fish species to the water level fluctuations and related environmental changes of the Amazon River. Amazoniana, 9, 315-351.

Kanazawa, A. (1985), Essential fatty acid and lipid requirement of fish. In: Grady, K. T. and Spillet, P. B. (eds.). Nutrition and Feeding in Fish. London : Academic Press. pp. 281-298.

Kinsella, J. E.; Shimp, J. L., Mai, J. and Weihrauch, J. (1977), Fatty acid content and composition of freshwater finfish. JAOCS, 54, 424-429.

Lansac-Tôha, F. A.; Lima, A. F.; Hahn, N. S. and Andrian, I. F. (1991), Composição da dieta alimentar de Hypophthalmus edentatus SPIX, 1829 (Pisces, Hypophthalmidae) no reservatório de Itaipu e no rio Ocoí. Revista UNIMAR, 13, 147-162.

Le Cren, E. D. (1951), The length-weight relationship and seasonal cycle in gonad weight and condition in the perch (Perca fluviatilis). J. Animal Ecol., 20, 201-219.

Mac Farlane, R. B.; Norton, E. C. and Bowers, M. J. (1993), Lipid dynamics in relation to the annual reproductive cycle in yellowtail rockfish (Sebastes flavidus). Can. J. Fishe. Aquat. Sci., 50, 391-401.

Maia, E. L. (1992), Otimização da metodologia para caracterização de constituintes lipídicos e determinação da composição em ácidos graxos e aminoácidos de peixes de água doce. Thesis, Universidade Estadual de Campinas, Campinas, Brazil.

Maia, E. L.; Rodriguez-Amaya, D. B. and AmayaFarfan, J. (1983), Proximate, fatty acid and amino acid composition of the Brazilian freshwater fish Prochilodus scrofa. Food Chem., 12275-286.

Pearson, D. (1973), Laboratory techniques in food analysis. New York: John Wiley and Sons.

Saint-Paul, U. (1984), Investigations on the seasonal changes in the chemical composition of liver and condition from a neotropical characoid fish Colossoma macropomum (Serrasalmidae). Amazoniana, 9, 147-158.

Siegel, S. (1975), Estatística não paramétrica para as ciências do comportamento. São Paulo : McGraw-Hill. pp. 209-218.

Viswanathan Nair, P. G. and Gopakumar, K. (1978), Fatty acid compositions of 15 species of fish from tropical waters. J. Food Sci., 43,1162-1164.

Wang, Y. J.; Miller, L. A.; Perren, M. and Addis, P. B. (1990), Omega-3 fatty acids in Lake Superior fish. $J$. Food Sci., 5571- 73, 76.

Zenebe, T.; Ahlgren, G.; Gustafsson, I. B. and Boberg, M. (1998), Fatty acid and lipid content of Oreochromis niloticus L. in Ethiopian lakes - dietary effects of phytoplankton. Ecol. Fresh. Fish, 7, 146-158.

Received: December 07, 2000; Revised: October 10, 2002; Accepted: May 13, 2002. 